\title{
REALIST AND COGNITIVE PERSPECTIVES ON \\ MEANING AND SEMANTICS
}

\section{GREGOR STRLE}

The article presents central paradigms on semantics and meaning. The aim is to introduce the reader of cultural studies to various aspects of modeling meaning and to provide a useful theoretical and methodological semantic apparatus. Various notions of meaning and semantics are examined from philosophical and cognitive perspectives. The author argues that meaning is a conventional entity and part of the social and cultural environment that emerges from the community of language users.

Keywords: meaning, semantics, representation, philosophy, cognition, culture
Prispevek predstavlja osrednje paradigme, ki obravnavajo semantiko in pomen jezika. Zainteresirane za kulturološke raziskave želi seznaniti z različnimi vidiki oblikovanja pomena in hkrati zagotoviti uporaben teoretski in metodoloski okvir. Dojemanje pomena in semantike je raziskano s filozofske in kognitivne perspektive. Avtor utemeljuje, da je pomen dogovorna entiteta, ki nastaja v družbenem in kulturnem okolju uporabnikov jezika.

Ključne besede: pomen, semantika, reprezentacija, filozofija, kognicija, kultura

\section{INTRODUCTION}

Much of cultural analysis seeks to uncover semantic structures of cultural artifacts and underlying modes of communication, including by deciphering various forms of their representation. These are inherently human, available to the receiver through the system of codes (linguistic or otherwise), and thus can only be understood through the collective (social, cultural, historical) denotation of meaning and context, and their respective modes of communication (Boas, 1932; Crick, 1976; Deacon, 1997; Richerson, Boyd, 2005). In his seminal book, William Foley states that anthropological linguistics:

is concerned with the place of language in its wider social and cultural context, its role in forging and sustaining cultural practices and social structures. [...] seeks to uncover the meaning behind use, misuse, or non-use of language [...] It is interpretative discipline peeling away at language to find cultural understanding. (Foley, 1997: 4)

Similarly, in his explorations of language and meaning, Malcolm Crick argues for semantic anthropology built upon "psychologically real" conceptual structure, language usage, and cultural meaning (Crick, 1976).

A review of the literature in cultural studies, however, reveals only a sparse repertoire on the topic of theoretical perspectives on language and meaning, the majority borrowed from anthropology and to a lesser extent from other disciplines in which the concept of 
meaning is more central, such as linguistics, philosophy of language, and cognitive science. It is no coincidence, then, that to this day the most important foundations for understanding language and meaning in cultural studies lie in the structuralism of Claude Lévi-Strauss (1955) and Noam Chomsky's generative grammar (1968), two widely used paradigms. Both paradigms were initiated in the middle of the previous century and advocate structural universalism that transcends language (see next section). Both have broader implications as theories of human cognition, constraining our being in the world via universal mental processes that define not only language but also human nature and culture. Chomsky's generative linguistics sees structural universals of language (universal grammar) as special kinds of cognitive constraints that are biologically fixed by innate structuring, and as such determinants of cognitive and cultural universalism. As a consequence, both structuralism and generative linguistics trivialize cultural diversity (Sampson, Babarczy, 2014), despite ample evidence for its existence and, on the other hand, lack of empirically verified linguistic universals.

The biological determinism of universal grammar is, of course, untenable from an empirical perspective and evidence-based field studies of language, culture, and cognition (e.g., Boas, 1932; Crick, 1976; Thomas, Kronenfeld, Kronenfeld, 1976; Boyd, Richerson, 1985; Foley, 1997; Glucksberg, 2003; Richerson, Boyd, 2005; Christiansen, Chater, 2008; Evans, Levinson, 2009; Sampson, Babarczy, 2014). Nicholas Evans and Stephen C. Levinson, for example, have reviewed decades of cross-linguistic research to illustrate "the ways languages vary radically in sound, meaning, and syntactic organization" (Evans, Levinson, 2009: 429). Their findings show language diversity is not merely superficial and that there is no empirical evidence to support generative linguistics (see also Christiansen, Chater, 2008). "The true picture is very different: languages differ so fundamentally from one another at every level of description (sound, grammar, lexicon, meaning) that it is very hard to find any single structural property they share" (ibid.). To this end, several researchers argue that languages have gradually adapted through (also cultural) evolution (for various views on this topic, see Boyd, Richerson, 1985; Durham, 1991; Dennet, 1995; Deacon, 1997; Richerson, Boyd, 2005; Christiansen, Chater, 2008). According to Morten Christiansen and Nick Chater, the structure of human language must inevitably be shaped around human learning and processing biases deriving from the structure of our thought processes, perceptuo-motor factors, cognitive limitations, and pragmatic constraints. (Christiansen, Chater, 2008: 490)

Languages, as main constituents of cultures, are not fixed by some innate and universally determined conceptual system as generative linguistics would have it. "[L]anguages reflect cultural preoccupations and ecological interests that are a direct and important part of the adaptive character of language and culture" (Evans, Levinson, 2009: 436).

In what follows, several notions of meaning and semantics will be investigated, both in the context of philosophical perspectives that underlie the above-mentioned deterministic paradigms, as well as by presenting an alternative, psychologically plausible account. 
The position taken in the article is that of cognitive semantics and understanding of meaning from empirical, evidence-based perspective. The aim is to give insight into various interpretations of meaning and semantics, as well as offer a viable theoretical apparatus for semantic analysis and interpretation of meaning in cultural studies.

\section{CORE QUESTIONS ON MEANING}

In general, a semantic theory postulates that the meaning of an expression is a certain kind of entity, and the basic concern of semantic theory is the nature of such an entity and the formalization of the relation between the two: the expression and its meaning. A theory of semantics should be able to answer four basic questions about meaning:

(1) What is meaning? (the ontological question)

(2) What is the relation between linguistic expressions and their meanings? (the semantic question)

(3) How can the meanings of linguistic expressions be learned? (the learnability question)

(4) How do we communicate meanings? (the communicative question).

(Gardenfors, 1999: 209)

The ontological question provides us with two competing semantic paradigms: realist semantics and cognitive semantics. The two paradigms differ on all of the above issues. In what follows, I will focus mainly on answering the ontological and semantic questions; the answers to the learnability and communication questions will be treated indirectly in this context.

\section{REALIST SEMANTICS}

The idea of structural universals, i.e. that there is an explicit set of properties and finite sets of formal rules that determine the structure of a language and its fixed grammaticality bounds (Chomsky, 1968), is rooted in mainstream philosophy of language and its realist account of language and meaning. Realist semantics stems from the philosophical movement that existed since Gottfried Wilhelm Leibnitz (1646-1716) and became dominant with the development of modern logic and the philosophy of Gottlob Frege (1848-1925), Bertrand Russell (1872-1970), Rudolf Carnap (1891-1970), and the early Ludwig Wittgenstein (18891951), among others. With the development of modern logic came ideas about propositional analysis of formal languages, i.e., how natural language might be formalized to conform to logical calculus. In Foundations of Arithmetic (1974 [1882]) and Sense and Reference (1980 [1892]), Frege laid the foundations by providing a logical formalism that formed the first 
predicate calculus (to represent the internal structure of sentences) and the truth-functional propositional calculus. In The Principles of Mathematics (1903), Russell further refined the propositional and predicate calculi and argued for making all aspects of meaning explicit: language and the world were viewed as logical structures, constructions of atomic facts based on logical primitives and truth-functional semantics. The content of a sentence is the proposition expressed. The focus is on propositional semantics, i.e. on the meanings of sentences, not of words. Frege claims: "Only in a proposition have the words really a meaning [...] It is enough if the proposition taken as a whole has a sense; it is this that confers on its parts their content" (Frege, 1974: 71).

\section{SENSE AND REFERENCE}

The underlying hypothesis common to all variants of realist semantics is Frege's theory of reference (Frege, 1980). In its simplest form, the theory of reference defines the meaning of an expression as its extension, that is, as extensional semantics. All meaning is grounded in extension: the extension of a proposition is its truth-value and the extension of an expression is its referent. The notion of truth occupies a central position in logic and semantics. It is reflected in truth-functional semantics and the principle of compositionality. The principle of compositionality explains how the reference of a complex expression is determined by the reference of its parts. Sentences have a compositional structure and are determined by their logical form and the extensions of their parts: simple expressions compose complex expressions, which in turn compose sentences. The focus is not on the meaning of an expression as a kind of special entity, but on the truth-value; that is, on the contribution of a single expression (via reference) to the determination of the truth-value of a sentence in which it occurs.

An obvious problem is how to deal with expressions that have no referent (e.g. 'Santa Claus') and for which no truth value can be determined. Another problem arises when two expressions have the same referent but differ in meaning. In "Über Sinn und Bedeutung" (1980), Frege argues that the expressions 'Phosphorus' (an ancient term for the morning star) and 'Hesperus' (the evening star) have the same extension, i.e. the same referent, a planet Venus, but not the same meaning. A similar case is put forward by Hilary Putnam's 'Twin Earth experiment' (Putnam, 1975) with the terms 'water' and 'H2O'. In such cases, the reference of an expression alone does not explain the contribution or role of the individual expression in determining the truth value of all the propositions in which it occurs. Frege argued that there is more to theory than reference. Knowing the difference between phosphorus and hesperus requires a cognitive effort, i.e., knowing the meaning. "Hesperus is Phosphorus" is cognitively significant, while "Hesperus is Hesperus" is not. Frege's solution to the problem is to define two components of meaning: sense (Ger. Sinn) and reference (Ger. Begriffsschrift). 
Now what is the relation between sense and reference? Frege argued that sense is the "cognitive value" or "mode of presentation" (Ger. Art des Gegebenseins) of the referent (Frege, 1980: 56). Any expression that has an extension also has a sense, and the difference in cognitive significance is a difference in sense - the sense reflects the cognitive significance (Chalmers, 2002). Expressions, then, have sense or content in addition to reference, i.e., a non-extensional aspect that also affects the truth value of a proposition. Thus, the sense determines the reference. According to this definition, two sentences can express different propositions (have different content) and have the same truth value, but not vice versa, i.e. two sentences expressing the same proposition (having the same content) cannot have different truth values. For example, the propositions "Hesperus is a planet" and "Phosphorus is a planet" have different meanings but the same referent. Similarly, "sense determines referent" also applies to expressions: two expressions with the same referent can differ in content or sense (think of morning star and evening star), but not vice versa (two expressions with the same content cannot differ in reference).

\section{POSSIBLE WORLDS}

The problem with extensional semantics is that it ascribes "sense determines reference" in a kind of rigid designator, where senses are objective and propositions are defined absolutely (in terms of true and false) as primary truth-bearers. Such objectivity does not comport well with the semantics of natural language, where most expressions are not rigid. There is no objective notion of meaning (of an expression) that could establish the same reference for every possible situation. A semantic theory for natural language should be able to explain how sense determines reference depending on a particular situation or context, even in situations where there is no referent.

Saul Kripke (1959) redefined Fregean extensional theory in terms of possible worlds: we can refer to something without having the whole set of properties of that thing. Kripke's modal logic is intensional and distinguishes between designation (the mode of a reference) and the way that reference is determined. Proper names and natural kinds still have a referent, but not in Fregean sense. Proper names and natural kinds are "rigid designators" for they designate the same object in every possible world. Non-rigid designators, on the other hand, can have different references relative to possible worlds. Instead of mapping the language onto a single primary world, as is the case in extensional semantics, the intensional semantics maps the language onto a set of possible worlds: "A possible world isn't a distant country that we are coming across [...] A possible world is given by the descriptive conditions we associate with it. [...] 'Possible worlds' are stipulated, not discovered [...]" (Kripke, 1980: 44).

The main difference between the two theories lies in the interpretation of meaning and reference to the world. In extensional semantics, the reference is direct and unmediated, and 
linguistic expressions correspond directly to objects in the world. In intensional semantics, linguistic expressions obtain their meaning indirectly through intensions.

\section{NATURAL KINDS}

Essential to realist theories of semantics is the logical, truth-conditional account of language based on the notions of reference, truth, and inference. Reality has a unique deterministic structure that is objectively referential. Language and thought correspond to entities and categories in the world via symbols, and the world is structured in such a way that correspondences between symbols and the world are possible. The goal is the "axiomatization" of thought (Russell, 1903).

What makes such correspondences to the world possible are 'natural kinds'. 'Natural kinds', says Putnam, have "some 'essential nature' which the thing shares with other members of the natural kind. What the essential nature is, is not a matter of language analysis but of scientific theory construction" (Putnam, 1975: 104). Natural kinds, then, represent something that exists in the world independently of human cognition and is only accessible through manipulation of symbolic structures. Putnam argues that such a model of reality, in which constituents are objectively determined to provide "exactly one true and complete description of the world," is not only false but unintelligible. Instead, he proposes the view of "internal realism," which is compatible with conceptual relativity, i.e., with the observation that truth depends primarily on the conceptual scheme we use, not on the "God's Eye View" of realist metaphysics (Putnam, 1981). Conceptual relativity is in the hands of individuals, it comes from our cognition and interaction with the world, not from some presupposed, definitive reality.

\section{REPRESENTATIONAL REALISM}

Within the realist tradition, extensional and intensional theories of semantics are divided by the question of whether our perceptual access to the physical world is direct or mediated. Extensional semantics posits an ontologically immediate and non-representational relation to the world. Intensional semantics, on the other hand, constitutes its reference through the representational symbol system that registers the presence of an object or relevant aspects of its character. The latter underlies classical representationalism, as it aims to explain our contact with physical objects as mediated by a form of mental representation based on symbol manipulation. As John Foster points out, "[i]n place of the claim that our perceptual access to the physical world is direct, it insists that the perceiving of a physical item is always mediated by the occurrence of something in the mind which represents its presence to us" (Foster, 2000: 1). 
We call this representational realism, where the external world is mediated by internal symbolic representations and cognition is defined as the manipulation of these abstract representations. Concepts become discrete symbols that correspond to entities and categories in the world. Our conceptual symbol system is innate and only becomes meaningful through its ability to correctly correspond to these entities and categories in the world. Our "mental representations must thus be 'semantically evaluable' - capable of being true or false, or referring correctly or failing to refer correctly" (Lakoff, 1987: 163). Representations reflect logical relations between entities and categories in the world, independent of belief, knowledge, perception, understanding, or other aspects of individual's cognition. The success of our interaction with the world depends on our ability to successfully represent this external reality: "[k]nowledge consists in correctly conceptualizing and categorizing things in the world and grasping the objective connections among thing in those categories" (Lakoff, 1987: 163). Concepts and categories of mind are mental representations of objects and categories in the world, detached from any kind of non-objective influences that might make our knowledge objectively inaccurate, such as products of the imagination (metaphor, metonymy, mental imagery, etc.). Thought then becomes a manipulation of abstract symbols that acquire their meanings through correspondence with entities and categories in the world (or possible worlds).

The realist account has several problems. In reality, most categories do not seem to have an ontological structure defined by a set of necessary and sufficient conditions. Take Lakoff's example of a category mother: there is the prototypical "birth mother" who bears and raises a child; a biological mother who provides genetic material but does not bear or raise the child; a surrogate mother who carries the child but does not provide genetic material; adoptive mothers; the mother of invention, etc. (Lakoff, 1987). The ambiguity of these examples makes the notion of an objective category unrealistic. Moreover, learning the meaning of words is not comparable to processing abstract symbol structures. Meaning cannot arise solely from the syntactic relations between arbitrary symbols; it must be rooted in our perceptions and actions. We must have access to mental content. This is called the problem of symbol grounding (Searle, 1980; Harnad, 1990): "Formal symbols by themselves can never be enough for mental contents, because the symbols, by definition, have no meaning (or interpretation, or semantics) except insofar as someone outside the system gives it to them" (Searle, 1980: 45).

The deterministic structure of realist semantics, it seems, could only be appropriate in matters of mathematics and logic. We can deduce from the realist definition that essential features constituting such categories are abstract, amodal, arbitrary elements which receive their meaning through a principle of compositionality. From the standpoint of cognitive psychology, such an approach has serious problems. In what follows, we will look at the cognitive account of language and the supporting empirical evidence that rejects the realist account of semantics. 


\section{COGNITIVE SEMANTICS}

The realist view prevailed until the mid-1970s, when alternative theories of semantics and language emerged. But the core critique came earlier, from philosophy itself. Beginning with Wittgenstein's (1953) rejection of the realist approach to language and meaning (including his own earlier work) as fundamentally misguided, Putnam's critique (1981), and later by other scholars, notably the phenomenological philosopher Hubert Dreyfus (1992) and anthropologist and cognitive psychologist Elanor Rosch (1973, 1978).

In Philosophical Investigations (1953), Wittgenstein argued that categories are not determined by necessary and sufficient conditions, as claimed by the realists, but are necessarily context-dependent. Using the concept of 'game' as an example, Wittgenstein argued that there is no single property common to all games on the basis of which we call them 'games'; instead, there is "a complicated network of similarities overlapping and crisscrossing: sometimes overall similarities, sometimes similarities of detail” (Wittgenstein, 1953: 66). Moreover, “[...] the term 'language-game' is meant to bring into prominence the fact that the speaking of language is part of an activity, or of a form of life" (ibid.: 23). Wittgenstein's investigations into everyday psychological concepts and language use had an important influence on the development of cognitive science and a number of highly influential theories of categorization and concept formation developed by Rosch. The introduction of the concept of "family resemblance" (which is based on the idea that grammar is arbitrary) led to Kuhnian paradigm shift towards cognitive theories of language.

Critically, there is a lack of empirical evidence to support the realist position on language and meaning. Experimental research in cognitive psychology, especially in the prototype theory introduced by Rosch $(1975,1978)$, has shown that categories do not conform to the rules of logic and the ontological view of the world as based on defining features. In most cases, the structure of a category is "graded" and "radial" - that is, the category has some central or prototypical members with peripheral members related to those central members, both by an extent of shared features and by metaphorical extension (Rosch, 1975; Lakoff, 1987; Lakoff, Johnson, 1980). The classical realist semantics, based on the set-theoretic model of necessary and defining features, is not psychologically real. The realist view has difficulty answering the question of learnability (3) precisely because of its exclusively formal semantics, divorced from the perceptual, sociological and cultural aspects of language and its users. There are no strict limits or ultimate lists of necessary and sufficient features or such criteria of category membership (Rosch, 1978; Smith, Medin, 1981, 1989; Lakoff, 1987).

\section{FINDINGS FROM COGNITIVE PSYCHOLOGY}

Several studies have demonstrated the category effect in semantic memory in terms of family resemblance: items in the same category are more related or similar than items in different 
categories (Rosch, 1973; Smith, Medin, 1981). In her studies on the psychological principles of categorization, Rosch defined cognitive economy and structure in the perceived world as the two key principles underlying the categorization system:

The first has to do with the function of category systems and asserts that the task of category systems is to provide maximum information with the least cognitive effort; the second has to do with the structure of the information so provided and asserts that the perceived world comes as structured information rather than as arbitrary or unpredictable attributes. Thus maximum information with least cognitive effort is achieved if categories map the perceived world structure as closely as possible. (Rosch, 1978: 28)

These principles further affect both horizontal and vertical categorization. The horizontal dimension concerns the prototype effect and "the segmentation of categories at the same level of inclusiveness - the dimension on which dog, cat, car, bus, chair, and sofa vary" (Rosch, 1978: 30). The vertical dimension, on the other hand, "concerns the level of inclusiveness of the category - the dimension along which the terms collie, dog, mammal, animal, and living thing vary." (ibid.).

There are other important considerations. There is strong empirical support for prototype theory and typicality (Rosch, 1973, 1975, 1978; Rips, Shoben, Smith, 1973; Mervis, Rosch, 1981; Lakoff, 1987). Prototype theory and the typicality effect suggest that within the same category, not all category members are the same; some are prototypical and others are less typical (Rosch, 1975). Thus, the notion of prototypicality is defined as "goodness of example", where the prototype is considered the best example among the members of a given category. To give a classic example of the evaluation of prototypicality (ibid.): for the category "bird", the robin, sparrow and bluebird are considered more representative than the chicken, penguin or emu.

What prototype theory purports to explain are the asymmetries between category members and asymmetric structures within categories. Prototyping effects and goodnessof-example ratings can be interpreted in terms of the internal structure of the category or of a category membership. To give just one example: some categories have "extendable boundaries" while others do not. For example, the category "bird" has strict boundaries in the sense that all members belong to it absolutely, i.e., something is not both a bird and a fish; a "big man," on the other hand, cannot be defined by itself, it needs a contrast class to compare with.

In many cases, prototypes act as cognitive reference points of various sorts and form the basis for inferences. The study of human inference is part of the study of human reasoning and conceptual structure, hence, those prototypes used in making inferences must be part of conceptual structure. It is important to 
bear in mind that prototype effects are superficial. They may result from many factors. In the case of a graded category like tall man, which is fuzzy and does not have rigid boundaries, prototype effects may result from degree of category membership, while in the case of bird, which does have rigid boundaries, the prototype effects must result from some other aspect of internal category structure. (Lakoff, 1987: 45)

The vertical dimension of a category system, on the other hand, gives an important insight into the relation between inclusiveness and abstractness of category structure, and the notion of basic level categories: "[...] not all possible levels of categorization are equally good or useful; rather, the most basic level of categorization will be the most inclusive (abstract) level at which the categories can mirror the structure of attributes perceived in the world" (Rosch, 1978: 30).

The vertical dimension has a taxonomic structure composed of different levels of abstraction - the greater the inclusion, the higher the level. The criteria for defining a particular level of abstraction are based on the probabilistic concept of cue validity (Rosch, 1978). What Rosch had found is that this basic level of categorization has important cognitive significance:

Superordinate categories have lower total cue validity and lower category resemblance than do basic-level categories, because they have fewer common attributes; in fact, the category resemblance measure of items within the superordinate can even be negative due to the high ratio of distinctive to common features. Subordinate categories have lower total cue validity than do basic categories, because they also share most attributes with contrasting subordinate categories; in Tversky's terms, they tend to be combined because the weight of the added common features tend to exceed the weight of the distinctive features. That basic objects are categories at the level of abstraction that maximizes cue validity and maximizes category resemblance is another way of asserting that basic objects are the categories that best mirror the correlational structure of the environment. (Rosch, 1978: 31)

Numerous empirical studies support basic-level categorization, e.g.: cross-cultural studies by (Berlin, 1972; Rosch, 1978), cross-domain studies (Tversky, Hemenway, 1984), studies on object categorization (Jolicoeur, Gluck, Kosslyn, 1984; Rosch, 1978; Murphy, 2002), studies on free-naming tasks (Rosch, 1975), studies on children's language development and reasoning (Karmiloff-Smith, 1992; Gelman, 1996; Medin, Waxman, 2007). 


\section{MEANINGS AS MENTAL ENTITIES}

The empirical findings played an important role in the development of cognitive theories of language and semantics. The theory of cognitive semantics challenges the classical realist view in all possible aspects. The main tenet of cognitive semantics is that "meanings are mental entities". This is in stark contrast to realist semantics, which maintains that sentences acquire their meanings by reference to real objects and events. As we have noted elsewhere, the problem with realist semantics lies in its objectivist metaphysics, which cannot account for language acquisition and comprehension or empirical findings on categorization. There are no objectively determined propositions or ultimate lists of necessary and sufficient features or conditions in the real world. Meanings must be perceptually grounded (Harnad, 1990). As such, realist semantics is not acceptable as a cognitive theory.

In cognitive semantics, the focus is on the graded structure of concepts and categories of natural language. The cognitive answer to the semantic question (2) is that words acquire their meanings through mappings to conceptual structure. Semantics becomes the relation (via a set of associations) between an expression and its conceptual structure - a mental representation of the individual language user, not an objectivist metaphysics. Instead of propositions, cognitive semantics operates on lexical meanings of words. Meaning becomes a conceptualization in a cognitive model (Gärdenfors, 2000).

In the same vein, the cognitivist answer to the learnability question (3) is that since meanings are conceptualizations, we obtain the meaning of an expression via an associative link with our cognitive structure. Language itself is seen as part of the cognitive structure, not as an entity isolated from the user. As meanings are mapped onto the conceptual structures of the individual, the notion of truth and objective reference to the external world become secondary; what matters is belief. The realist view has difficulty answering the question of learnability (3) because its deterministic semantics is detached from the user.

Moreover, such meaning is grounded. Cognitive semantics offers a natural explanation for the relationship between perceptual and cognitive mechanisms and the perceptual "grounding" of meaning:

Since the cognitive structures in our heads are created mainly by our perceptual mechanisms, directly or indirectly, it follows that meanings are, at least partly, perceptually grounded. This, again, is in contrast to traditional realist versions of semantics which claim that since meaning is a mapping between the language and the external world (or several worlds), meaning has nothing to do with perception. A consequence of this is also that language and semantics is not seen as separated from other forms of cognition, but interacts with perception, memory, concept formation, etc. (Gärdenfors, 1999: 211) 


\section{IMAGE-SCHEMATIC REPRESENTATIONS}

The unique approach of cognitive semantics is ultimately revealed in its formalization. Unlike syntactic systems, cognitive models are image schematic and based on geometric constructions, not propositions (Gärdenfors, 2000). Image-schemas reflect the systematic relationships of the elements that make up a language, but are not like words in a language. They are abstract mental images with inherent spatial structure that is schematic, not pictorial. Since cognitive semantics emphasizes the relationship between language and cognitive structure, semantic elements are modeled as spatial or topological objects. An image schema is "[...] a recurring structure of or within our cognitive processes, which establishes patterns of understanding and reasoning. Image schemas emerge from our bodily interactions, linguistic experience and historical context" (Johnson, 1987: 256). There are many variations of image schemas, but all share the general feature of an inherent spatial structure consisting of spaces or basic areas:

It is however necessary to posit a number of 'basic domains', that is, cognitively irreducible representational spaces or fields of conceptual potential. Among these basic domains are the experience of time and our capacity for dealing with two and three-dimensional spatial configurations. There are basic domains associated with various senses: color space (an array of possible color sensations), coordinated with the extension of the visual field; the pitch scale; a range of possible temperature sensations (coordinated with positions on the body); and so on. Emotive domains must also be assumed. It is possible that certain linguistic predications are characterized solely in relation to one or more basic domains, for example time for (BEFORE), color space for (RED), or time and the pitch scale for (BEEP). However, most expressions pertain to higher levels of conceptual organization and presuppose nonbasic domains for their semantic characterization. (Langacker, 1987: 5)

Moreover, George Lakoff and Mark Johnson (1980) argue that the main vehicles of conceptual interactions between these domains are metaphorical and metonymic operations (the aspects of natural language that are completely ignored by the realist approach):

We discovered that the image-schema structure of the source domain is used in reasoning about the target domain. Moreover, by looking at hundreds of cases, we found that image-schema structure and image-schematic inferences seemed to be "preserved" by metaphors. That is, source domain containers (e.g., physical traps) are mapped to containers (e.g., metaphorical traps), with interiors mapped to interiors and exteriors mapped to exteriors. (Lakoff, Johnson, 1980: 253) 
There are a variety of cognitive theories with different formulations of figurativeschematic models of meaning. They diverge on representation and embodiment (Varela, Thompson, Rosch, 1991), consciousness (Johnson, Lakoff, 2002; Talmy, 2000; Evans, 2003), degree of abstraction (Grady, 2005), dynamics (Mandler, 2004), sensory modality (Ziemke, Zlatev, Frank, 2007), and intersubjectivity (Tomasello et al., 2005), among others. The main reason for this heterogeneity in the field lies in the wide range of cognitive research. In cognitive semantics, semantic structure is a part of cognitive mechanisms, especially perception and memory. Therefore, the study of semantics is inherently related to the study of other, more general aspects of cognition.

The idea is that since the acquisition and use of language rest on an experiential basis, and since experience of the world is filtered through extralinguistic faculties such as perception and memory, language will of necessity be influenced by such faculties. We can therefore expect the nature of human perceptual and cognitive systems to be of significant relevance to the study of language itself. One of the primary tasks of cognitive linguistics is the ferreting out of links between language and the rest of human cognition. (Regier, 1996: 27)

The main problem with image-schematic models is the lack of a precise definition or formalism of what constitutes an image-schematic representation. Image-schematic representations typically use a concept of space that "serves as a basic conceptual structuring device in language" (Regier, 1996: 19). However, without further constraints, such a general notion of topological or geometric structure is too opaque and difficult to implement. To this end, several alternative solutions have been proposed using mathematically defined models of representation (e.g., Gärdenfors, 2000), which also provide psychologically plausible explanations for basic human cognitive processes of categorization and concept formation.

\section{CONCLUSIONS}

In Western culture, we have become accustomed to the realist worldview that has prevailed since the time of Aristotle. The goal of the realist paradigm is "axiomatization" of thought: reality comes with a definite deterministic structure that is objectively referential. Realist semantics is about the relationship between the abstract language system and aspects of the world. Its objectivist metaphysics emphasizes the reality of the world, in which linguistic categories are defined as sets of necessary and sufficient conditions that depend strictly on reference to things in the world. Language and thought correspond to entities and categories in the world via symbols, and the world is structured in such a way that correspondences between symbols and the world are possible. 
There are many logical and empirical problems with the realist account and its objectivist metaphysics. As empirical findings show, concepts and categories do not conform to the ontological structure of realism. The realist account also has difficulty explaining essential aspects of natural language and its use, such as: how meanings are grasped by individual language users, how perception affects categorization and cognition in general, how concepts and categories emerge, how we fill in partial information, or how semantic memory works, to name a few. Ultimately, the realist view has difficulty answering the question of semantics (2) and learnability (3) precisely because of its objectivist semantics, divorced from perception, sociological and cultural aspects of language and its users.

Philosophical 'possible worlds' imply ontological stances that cannot explain, without justification, what is intuitively meaningful to individual language users (Brandt, 2005). On the contrary, linguistic meanings are conventional entities and part of the social and cultural environment determined by the 'linguistic power structure' that emerges from the community of language users (Gärdenfors, 2000). As discussed, the idea of structural universalism, that a human language has fixed grammaticality boundaries, is untenable from an empirical perspective (e.g. Christiansen, Chater, 2008; Evans, Levinson, 2009). In the tradition of Boas, Martin Joos pointed out that languages should be approached "without any preexistent scheme of what a language must be" (Joos, 1957: V.), since languages can "differ from each other without limit and in unpredictable ways" (ibid.: 96).

\section{REFERENCES}

Berlin, Brent. 1972. Speculations on the Growth of Ethnobotanical Nomenclature. Language in Society 1: 51-86. DOI: https://doi.org/10.1017/S0047404500006540.

Boas, Franz. 1932. The Aims of Anthropological Research. Science 76: 605-613. DOI: https://doi. org/10.1126/science.76.1983.605.

Boyd, Robert, and Peter J. Richerson. 1985. Culture and the Evolutionary Process. Chicago: University of Chicago Press.

Chalmers, David J., ed. 2002. Philosophy of Mind: Classical and Contemporary Readings. New York: Oxford University Press.

Chomsky, Noam. 1968. Language and Mind. New York: Harcourt, Brace \& World.

Christiansen, Morten, and Nick Chater. 2008. Language as Shaped by the Brain. Behavioral and Brain Sciences 31 (5): 489-509. DOI: https://doi.org710.1017/S0140525X08004998.

Crick, Malcolm. 1976. Explorations in Language and Meaning: Towards a Semantic Anthropology. New York: Wiley.

Deacon, Terrence William. 1997. The Symbolic Species: The Co-evolution of Language and the Brain. Cambridge: Norton and Company.

Dennett, Daniel C. 1995. Darwin's Dangerous Idea: Evolution and the Meanings of Life. New York: Simon \& Schuster. 
Dreyfus, Hubert. 1992. What Computers Still Can't Do. Cambridge: MIT Press.

Durham, William H. 1991. Coevolution: Genes, Culture, and Human Diversity. Stanford: Stanford University Press.

Evans, Nicholas, and Stephen C. Levinson. 2009. The Myth of Language Universals: Language Diversity and Its Importance for Cognitive Science. Behavioral and Brain Sciences 32: 429-448. DOI: https:// doi.org/10.1017/S0140525X0999094X.

Evans, Vyvyan. 2003. The Structure of Time: Language, Meaning and Temporal Cognition. Amsterdam: Benjamins.

Foley, William A. 1997. Anthropological Linguistics: An Introduction. Malden: Blackwell Publishers.

Foster, John. 2000. The Nature of Perception. New York: Oxford University Press. DOI: https://doi.org/1 0.1093/0198237693.001.0001.

Frege, Gottlob. 1974 (1884). The Foundations of Arithmetic: A Logic-Mathematical Enquiry into the Concept of Number. Oxford: Blackwell. [Orig. Die Grundlagen der Arithmetik: eine logisch-mathematische Untersuchung über den Begriff der Zabl. Breslau: w. Koebner.]

Frege, Gottlob. 1980 (1892). On Sense and Reference. Translations from the Philosophical Writings of Gottlob Frege, ed. Peter Geach, Max Black. Oxford: Blackwell. [Orig. Über Sinn und Bedeutung. Zeitschrift für Philosophie und philosophische Kritik 100: 25-50.]

Gärdenfors, Peter. 1999. Does Semantics Need Reality? In Understanding Representation in the Cognitive Sciences, eds. Alexander Riegler, Markus Peschl and Astrid von Stein. New York: Kluwer Academic/ Plenum Publishers, 209-217. DOI: https://doi.org/10.1007/978-0-585-29605-0_23.

Gärdenfors, Peter. 2000. Conceptual Spaces: The Geometry of Thought. Cambridge: MIT Press. DOI: https:// doi.org/10.7551/mitpress/2076.001.0001.

Gelman, Susan. 1996. Concepts and Theories. In Perceptual and Cognitive Development: Handbook of Perception and Cognition, eds. Rochel Gelman and Terry K. Au, 117-150. San Diego: Academic Press. DOI: https://doi.org/10.1016/B978-012279660-9/50022-1.

Glucksberg, Sam. 2003. The Psycholinguistics of Metaphor. Trends in Cognitive Sciences 7 (2): 92-96. DOI: https://doi.org/10.1016/S1364-6613(02)00040-2.

Grady, Joseph. 2005. Image Schemas and Perception: Refining a Definition. In From Perception to Meaning: Image Schemas in Cognitive Linguistics, ed. Beate Hampe. 21-35. Berlin: Mouton. DOI: https:// doi.org/10.1515/9783110197532.1.35.

Harnad, Steven. 1990. The Symbol Grounding Problem. Physica 42: 335-346.

Johnson, Mark. 1987. The Body in the Mind: The Bodily Basis of Reason and Imagination. Chicago: University of Chicago Press. DOI: https://doi.org/10.7208/chicago/9780226177847.001.0001.

Johnson, Mark, and George Lakoff. 2002. Why Cognitive Linguistics Requires Embodied Realism. Cognitive Linguistics 13: 245-263. DOI: https//doi.org/10.1515/cogl.2002.016.

Jolicoeur, Pierre, Mark A. Gluck, and Stephen Kosslyn, S. M. 1984. Pictures and Names: Making the Connection. Cognitive Psychology 16: 243-275. DOI: https//doi.org/10.1016/0010-0285(84)90009-484.

Joos, Martin, ed., 1957. Readings in Linguistics. Washington: American Council of Learned Societies.

Karmiloff-Smith, Annette. 1992. Beyond Modularity: A Developmental Perspective on Cognitive Science. Cambridge: MIT Press.

Kripke, Saul. 1959. A Completeness Theorem in Modal Logic. Journal of Symbolic Logic 24: 1-24. DOI: https://doi.org/10.2307/2964568.

Kripke, Saul. 1980. Naming and Necessity. Cambridge: Harvard University Press. 
Lakoff, George. 1987. Women, Fire, and Dangerous Things: What Categories reveal about the Mind. Chicago: University of Chicago Press. DOI: https://doi.org/10.7208/chicago/9780226471013.001.0001.

Lakoff, George, and Mark Johnson. 1980. Metaphors We Live By. Chicago: University of Chicago Press.

Langacker, Ronald. 1987. Foundations of Cognitive Grammar. Stanford: Stanford University Press.

Lévi-Strauss, Claude. 1955. The Structural Study of Myth. Journal of American Folklore 68: 428-444. DOI: https://doi.org/10.2307/536768.

Mandler, Jean Matter. 2004. The Foundations of Mind: Origins of Conceptual Thought. Oxford: Oxford University Press.

Medin, Douglas L. 1989. Concepts and Conceptual Structure. American Psychologist 44 (12): 1469-1481. DOI: https://doi.org/10.1037/0003-066X.44.12.1469.

Medin, Douglas L., and Sandra Waxman. 2007. Interpreting Asymmetries of Projection in Children's Inductive Reasoning. In Inductive Reasoning: Experimental, Developmental, and Computational Approaches, eds. Aidan Feeney and Evin Heit, 55-80. Cambridge: Cambridge University Press. DOI: https://doi.org/10.1037/0003-066X.44.12.1469.

Mervis, Carolyn. B., and Elanor Rosch. 1981. Categorization of Natural Objects. Annual Review of Psychology 32 (1): 89-115. DOI: https://doi.org/10.1146/annurev.ps.32.020181.000513.

Murphy, Gregory L. 2002. The Big Book of Concepts. Cambridge: The MIT Press. DOI: https://doi. org $/ 10.7551 / \mathrm{mitpress} / 1602.001 .0001$.

Patterson, Richard, 1995. Aristotle's Modal Logic: Essence and Entailment in the Organon. Cambridge: Cambridge University Press. DOI: https://doi.org/10.1017/CBO9780511609015.

Putnam, Hilary. 1975. The Meaning of "Meaning". In Mind, Language and Reality, ed. Hilary Putnam, 215-271.. Cambridge: Cambridge University Press. DOI: https://doi.org/10.1017/CBO9780511625251.014.

Putnam, Hilary. 1981. Reason, Truth, and History. Cambridge: Cambridge University Press. DOI: https:// doi.org/10.1017/CBO9780511625398.

Regier, Terry. 1996. The Human Semantic Potential: Spatial Language and Constrained Connectionism. Cambridge: MIT Press.

Richerson, Peter.J., and Robert Boyd. 2005. Not by Genes Alone: How Culture Transformed Human Evolution. Chicago: Chicago University Press.

Rips, Lance J., Edward J. Shoben, and Edward E. Smith. 1973. Semantic Distance and the Verification of Semantic Relations. Journal of Verbal Learning and Verbal Behavior 12: 1-20. DOI: https://doi. org/10.1016/S0022-5371(73)80056-8.

Rosch, Elanor. 1973. On the Internal Structure of Perceptual and Semantic Categories. Cognitive Development and the Acquisition of Language 12: 308.

Rosch, Elanor. 1975. Cognitive Representations of Semantic Categories. Journal of Experimental Psychology: General 104: 192-233. DOI: https://doi.org/10.1037/0096-3445.104.3.192.

Rosch, Elanor. 1978. Principles of Categorization. In Cognition and Categorization, ed. Eleanor Rosch, and Barbara B. Lloyd. Hillsdale: Lawrence Erlbaum Associates.

Russell, Bertrand. 1903. The Principles of Mathematics. Cambridge: Cambridge University Press.

Sampson, Geoffrey, and Anna Babarczy. 2014. Grammar Without Grammaticality. Berlin, Boston: De Gruyter Mouton.

Searle, John. 1980. Minds, Brains and Programs. Behavioral and Brain Sciences 3: 417-457. DOI: https:// doi.org/10.1017/S0140525X00005756. 
Smith, Edward E, and Douglas L. Medin. 1981. Categories and Concepts. Cambridge: Harvard University Press. DOI: https//doi.org/10.4159/harvard.9780674866270.

Talmy, Leonard. 2000. Toward a Cognitive Semantics: Vol. 1-2. Cambridge: MIT Press.

Thomas, Lynn, Judy Kronenfeld, and David Kronenfeld. 1976. Asdiwal Crumbles: A Critique of LéviStraussian Myth Analysis. American Ethnologist 3: 147-173. DOI: https://doi.org/10.1525/ ae.1976.3.1.02a00090.

Tomasello, Michael. 2003. Constructing a Language: A Usage-Based Theory of Language Acquisition. Cambridge: Harvard University Press.

Tversky, Barbara, and Kathleen Hemenway. 1984. Objects, Parts, and Categories. Journal of Experimental Psychology: General 113: 169-197. DOI: https://doi.org/10.1037/0096-3445.113.2.169.

Varela, Francisco, Evan Thompson, and Elanor Rosch. 1991. The Embodied Mind: Cognitive Science and Human Experience. Cambridge: MIT Press. DOI: https://doi.org/10.7551/mitpress/6730.001.0001.

Wittgenstein, Ludwig. 1953. Philosophical Investigations. Oxford: Blackwell.

Ziemke, Tom, Jordan Zlatev, and Roslyn M. Frank. 2007. Body, Language and Mind: Vol. 1: Embodiment. Berlin: Mouton de Gruyter.

\section{REALISTIČNI IN KOGNITIVNI POGLEDI NA POMEN IN SEMANTIKO}

Prispevek predstavlja osrednje paradigme, ki obravnavajo semantiko in pomen $v$ naravnem jeziku. Zaintereseirane za kulturološke raziskave želi seznaniti z različnimi vidiki oblikovanja pomena in mu hkrati ponuditi za raziskovanje uporaben teoretski in metodološki okvir.

Različni odtenki pomena in semantike so bili preučeni s filozofske in kognitivne perspektive. Realistična semantika se nanaša na razmerje med abstraktnim jezikovnim sistemom in vidiki sveta. Resničnost se kaže v določeni deterministični strukturi, ki je objektivno referenčna. Takšna objektivistična metafizika poudarja resničnost sveta, v katerem so jezikovne kategorije opredeljene kot niz nujnih in zadostnih pogojev; te kategorije so določno odvisne od reference na stvariv zunanjem svetu. Z realističnega vidika je torej jezik osmišljen zgolj s svojo zmožnostjo, da pravilno ustreza entitetam in kategorijam $v$ svetu. Reprezentacija pomena je tako reprezentacija zunanje relanosti, je ogledalo logičnih razmerij, ki niso neodvisna od posameznikovega verjetja, zaznavanja, znanja, razumevanja ali katerega koli drugega vidika njihovega spoznavanja. Človekova uspešna interakcija s svetom je tako odvisna od njegove sposobnosti uspeřnega predstavljanja te zunanje resničnosti. Misel postane manipulacija z abstraktnimi simboli, ki svoj pomen dobijo v ujemanju z objektivno opredeljenimi entitetami in kategorijami. Bistvene značilnosti, ki tvorijo takšne kategorije, so abstraktni, amodalni, poljubni elementi, ki dobijo svoj pomen po načelu kompozicije. Takšna deterministična struktura kategorij in konceptov je uporabna zlasti na področju matematike in logike.

$Z$ vidika kognitivne semantike so omenjene predpostavke realistične semantike logično in empirično sporne. Empirične ugotovitve kognitivne psihologije kažejo, da se v smislu nujnih in 
zadostnih pogojev kategorizacije ne ujemajo s pravili logike in ontološkega pogleda na svet. $V$ večini primerov je struktura kategorij "radialna" - to pomeni, da kategorijo tvori nekaj osrednjih primerov ali prototipov z drugimi primeri, ki so bolj ali manj povezani zosrednjimi. Učenje pomenov besed ni zgolj obdelava simbolnih abstraktnih struktur. Pomen je namrec konceptualna entiteta, na katero vplivajo posameznikova prepričanja, znanje in kontekst.

Dr. Gregor Strle, ZRC SAZU, Institute of Ethnomusicology; University of Ljubljana, Faculty of Electrical Engineering, gregor.strle@zrc-sazu.si

The author acknowledges that the research project (No. J7-9426) Misliti folkloro: Folkloristicne, etnološke in računske perspektive in pristopi k narečju / Thinking Folklore: Approaching Dialect from Folkloristic, Ethnological, and Computational Perspectives was financially supported by the Slovenian Research Agency. 